\title{
Investigations on Mechanical and Tribological Behaviour of Particulate Filled Glass Fabric Reinforced Epoxy Composites
}

\author{
Bhadrabasol Revappa Raju1*, Bheemappa Suresha², Ragera Parameshwarappa Swamy², \\ Bannangadi Swamy Gowda Kanthraju ${ }^{4}$ \\ ${ }^{1}$ Department of Mechanical Engineering, PES Institute of Technology and Management, Shivamogga, India \\ ${ }^{2}$ Department of Mechanical Engineering, The National Institute of Engineering, Mysore, India \\ ${ }^{3}$ Department of Mechanical Engineering, University B.D.T. College of Engineering, Davangere, India \\ ${ }^{4}$ Department of Mechanical Engineering, Don Bosco Institute of Technology, Bangalore, India \\ Email: 'rajusrujan@gmail.com
}

Received April 6, 2013; revised May 25, 2013; accepted June 12, 2013

Copyright (C) 2013 Bhadrabasol Revappa Raju et al. This is an open access article distributed under the Creative Commons Attribution License, which permits unrestricted use, distribution, and reproduction in any medium, provided the original work is properly cited.

\begin{abstract}
The aim of the research article is to study the mechanical and two-body abrasive wear behaviour of alumina $\left(\mathrm{Al}_{2} \mathrm{O}_{3}\right)$ filled glass fabric reinforced epoxy (G-E) composites. Alumina filled G-E composites containing 0, 5, 7.5 and $10 \mathrm{wt} \%$ were prepared using the hand lay-up technique followed by compression molding. The mechanical properties such as tensile strength, hardness and tensile modulus were investigated in accordance with ASTM standards. Two-body abrasive wear studies were carried out using a pin-on-disc wear tester under multi-pass condition against the water proof silicon carbide abrasive paper. From the experimental investigation, it was found that the presence of $\mathrm{Al}_{2} \mathrm{O}_{3}$ filler improved the tensile strength and tensile modulus of the $\mathrm{G}-\mathrm{E}$ composite. Inclusion of $\mathrm{Al}_{2} \mathrm{O}_{3}$ filler reduced the specific wear rate of G-E composite. The results show that in abrasion mode, as the filler loading increases the wear volume decreases and increased with increasing abrading distance. The excellent wear resistance was obtained for $\mathrm{Al}_{2} \mathrm{O}_{3}$ filled G-E composites. Furthermore, $10 \mathrm{wt} \%$ filler loading gave a very less wear loss. Finally, the scanning electron microscopic observations on the wear mechanisms $\mathrm{Al}_{2} \mathrm{O}_{3}$ filled $\mathrm{G}-\mathrm{E}$ composites was discussed.
\end{abstract}

Keywords: $\mathrm{Al}_{2} \mathrm{O}_{3}$ Filled G-E; Mechanical Properties; Two-Body Abrasive Wear; Scanning Electron Microscopy

\section{Introduction}

Polymer based materials are finding increasing use in many applications owing to their strength, lightness, ease of processing and availability of wider choice of systems [1]. Polymer and their composites are finding ever increasing usage for numerous industrial applications such as bearing material, rollers, seals, gears, cams, wheels, clutches and transmission belts etc. [2-5]. The importance of tribological properties convinced many researchers to study the wear behaviour and to improve the wear resistance of polymeric composites. For fiber reinforced polymer matrix composites, the process of material removal in the abrasive wear process involves four different mechanisms microploughing, microcutting, microfatigue and microcracking [6].

${ }^{*}$ Corresponding author.
Wear is defined as damage to a solid surface, generally involving progressive loss of material, due to relative motion between that surface and contacting substance or substances [7]. Abrasive wear is the most important among all the forms of wear because it contributes almost $64 \%$ of the total cost of wear [8]. Abrasive wear is caused due to hard particles or hard protuberances that are forced against and move along a solid surface [9]. In two-body abrasion, wear is caused by hard protuberances on one surface which can only slide over the other. Tribo-engineering materials and are invariably used in mechanical components, where wear performance in nonlubricated condition is a key parameter in the material selection $[10,11]$. Carbon, graphite, glass and aramid fabrics are the most commonly used fabrics for fiber reinforced polymer composites especially for making tribocomponents and aircraft structures that encounter harsh 
operating conditions such as high stresses, speeds, temperatures, etc. [12-14].

However, the woven fabric composites are getting acceptance in many engineering applications such as in circuit board, marine, aerospace, transportation and other industries for several reasons. They are commonly used in industry to manufacture composite components due to their ease of use, improve structural performance and reduction in cost. They provide better resistance to impact than unidirectional composites and display behavior that is closer to that of a fully isotropic material [14-16]. Modification of woven fabric reinforced composites by incorporation of fillers has been a popular research activity in the plastics industry since the properties of the resultant materials may be significantly changed by the introduction of fillers and fabrics [17].

A literature survey indicated that the short fiber reinforcement, in general, led to the deterioration in the abrasive wear resistance of the matrix [18]. Fabric reinforcement, on the other hand, improved the abrasion resistance of the polymers [19]. Many researchers studied the two-body wear behaviour of polymers in general and polymer composites in particular [20-25]. In some of the literature concerning abrasive wear of polymers, Friedrich [26] investigated the abrasive wear behaviour of the epoxy reinforced with carbon, glass and aramid fabrics and reported the wear performance of the fabrics in the order Aramid $>$ glass $>$ carbon. Bijwe et al., [28] tested polyamide 6 , polytetrafluoroethylene (PTFE) and their various composites in abrasive wear under dry and multi-pass conditions against silicon carbide (SiC) paper on pin-on-disc arrangement. Suresha et al. [29] investigated the friction and wear behavior of glass-epoxy composite with and without graphite. They fabricated neat glass-epoxy composite and graphite filled glass-epoxy composite with three different percentages of filler. They concluded the graphite filled glass epoxy composite shows higher resistance to sliding wear as compared to plain glass-epoxy composites. To evaluate the possibility of improving the mechanical and abrasive wear of glass fabric reinforced epoxy composites and elucidate the abrasive wear mechanisms, In view of the above, this research article reports a study on mechanical and two-body abrasive wear performance of unfilled and $\mathrm{Al}_{2} \mathrm{O}_{3}$ filled $\mathrm{G}-\mathrm{E}$ composites.

\section{Experimental Details}

\subsection{Materials and Fabrication}

The matrix material system selected is an Epoxy resin (LAPOX L-12 with density $1.16 \mathrm{~g} / \mathrm{cm}^{3}$ ) supplied by ATUL India Ltd., Gujarat, India. Woven glass plain weave fabrics made of $360 \mathrm{~g} / \mathrm{m}^{2}$, containing E-glass fibers of diameter of about $12 \mu \mathrm{m}$ have been used as the reinforcing material in all the composites. The fillers chosen were aluminum oxide $\left(\mathrm{Al}_{2} \mathrm{O}_{3}\right)$. The average particle size of $\mathrm{Al}_{2} \mathrm{O}_{3}$ micro particles is about $10 \mu \mathrm{m}$ size. The details of the constituents selected for the present work are listed in Table 1. As regards to the processing, on a Teflon sheet, E-glass woven fabric was placed over which the epoxy matrix system consisting of epoxy and hardener was smeared. Dry hand lay-up technique was employed to fabricate the composites. The stacking procedure consists of placing the fabric one above the other with the resin mix well spread between the fabrics. A porous Teflon film was again used to complete the stack. To ensure uniform thickness of the sample, a $3 \mathrm{~mm}$ spacer was used. The mould plates were coated with release agent in order to aid the ease of separation on curing. The cast of each composite after $12 \mathrm{~h}$ of impregnation and dried for $2 \mathrm{~h}$ at $100^{\circ} \mathrm{C}$ followed by compression molding at a temperature of $390^{\circ} \mathrm{C}$ and a pressure of 7.35 $\mathrm{MPa}$. The slabs so prepared measured $250 \mathrm{~mm} \times 250 \mathrm{~mm}$ $\times 3 \mathrm{~mm}$ in size. To prepare different $\mathrm{wt} \%$ of $\mathrm{Al}_{2} \mathrm{O}_{3}$ filled G-E composites, besides the epoxy hardener mixture, additional wt $\%$ of $\mathrm{Al}_{2} \mathrm{O}_{3}$ particles were included to form the resin mix. The details of the composites selected for the present work are listed in Table 2. The percentage of the glass fiber in the composite is 60 by wt $\%$. Mechanical and abrasive wear test samples were prepared according to ASTM standard from the cured laminates using a diamond tipped cutter.

\subsection{Physico-Mechanical Tests}

The density of the composites was determined by using a high precision electronic balance (Mettler Toledo, Model

Table 1. Physical and mechanical properties of the constituents selected for the present work.

\begin{tabular}{cccc}
\hline Property & Epoxy & Glass fibers & $\mathrm{Al}_{2} \mathrm{O}_{3}$ filler \\
\hline Density $\left(\mathrm{g} / \mathrm{cm}^{3}\right)$ & 1.16 & 2.54 & 3.89 \\
Tensile strength $(\mathrm{MPa})$ & 110 & 3400 & $260-300$ \\
Tensile modulus $(\mathrm{GPa})$ & 4.1 & 72.3 & 375 \\
\hline
\end{tabular}

Table 2. Composites selected for the present study.

\begin{tabular}{cccc}
\hline Sample name (designation) & $\begin{array}{c}\text { Glass fiber } \\
(\mathrm{wt} \%)\end{array}$ & $\begin{array}{c}\text { Epoxy } \\
(\mathrm{wt} \%)\end{array}$ & $\begin{array}{c}\mathrm{Al}_{2} \mathrm{O}_{3} \text { filler } \\
(\mathrm{wt} \%)\end{array}$ \\
\hline $\begin{array}{c}\text { Glass fabric reinforced epoxy } \\
(\mathrm{G}-\mathrm{E})\end{array}$ & 60 & 40 & - \\
$\begin{array}{c}\text { Aluminium oxide filled G-E } \\
\left(5 \% \mathrm{Al}_{2} \mathrm{O}_{3}-\mathrm{G}-\mathrm{E}\right)\end{array}$ & 60 & 35 & 5 \\
$\begin{array}{c}\text { Aluminium oxide filled G-E } \\
\left(7.5 \% \mathrm{Al}_{2} \mathrm{O}_{3}-\mathrm{G}-\mathrm{E}\right)\end{array}$ & 60 & 32.5 & 7.5 \\
$\begin{array}{c}\text { Aluminium oxide filled G-E } \\
\left(10 \% \mathrm{Al}_{2} \mathrm{O}_{3} \text {-G-E) }\right.\end{array}$ & 60 & 30 & 10 \\
\hline
\end{tabular}


AX 205) using the Archimedes principle. Hardness (Shore-D) of the samples was measured as per ASTM D2240, by using a Hiroshima make hardness tester (Durometer). Five readings at different locations were noted and average value is reported. Tensile properties were measured using a Universal testing machine in accordance with the ASTM D-3039 procedure at a cross head speed of $5 \mathrm{~mm} / \mathrm{min}$ and a gauge length of $50 \mathrm{~mm}$. The tensile strength and modulus were determined from the stress-strain curves. Five samples were tested in each set and the average value was reported. The tensile test was carried out on a fully automated Lloyd LR-20 kN Universal testing machine connected to a computer with DAPMAT software.

\subsection{Two-Body Abrasive Wear Test}

Two-body abrasive wear tests were performed using a Pin-on-Disc machine according to ASTM G99 standards. Test samples were prepared after proper cutting and polishing to $6 \mathrm{~mm} \times 6 \mathrm{~mm} \times 3 \mathrm{~mm}$ size. The composite sample was abraded against the water proof silicon carbide (SiC) abrasive papers of 320 and 600 grit size at a constant running speed of $175 \mathrm{rpm}$ in multi-pass condition Figures 1(a) and (b). During wear test, the sample is so placed in such a way that the fibers are parallel and anti-parallel with respect to the abrading direction and the abrading plane. A constant normal load of $10 \mathrm{~N}$ was applied. The weight loss measurements were carried out for four abrading distance of 7.5, 15, 22.5 and $30 \mathrm{~m}$. Before and after wear testing, samples were cleaned with brush to remove wear debris. The wear was measured by the loss in weight (Mettler: TOLEDO, $0.1 \mathrm{mg}$ accuracy), which was then converted into wear volume using the measured density data.

The specific wear rate $\left(K_{s}\right)$ was calculated from the equation:

$$
K_{s}=\frac{\Delta V}{L \times D} \mathrm{~m}^{3} / \mathrm{Nm}
$$

where $\Delta V$ is the volume loss in $\mathrm{m}^{3}, L$ is the load in Newtons and $D$ is the abrading distance in meters.

After wear test, the worn surfaces of specimens were examined using a scanning electron microscope (JSM 840A model and JEOL make). Before the examinations, a thin gold film was coated on the worn surface by sputtering to achieve a conducting layer.

\section{Results and Discussion}

\subsection{Effect of Filler Loading on Density}

The measured densities of the samples are listed in Table 3. Comparing the results it was observed that the inclusion of ceramic filler into $\mathrm{G}-\mathrm{E}$ showed higher density. The density of $10 \mathrm{wt} \% \mathrm{Al}_{2} \mathrm{O}_{3}$ filled $\mathrm{G}-\mathrm{E}$ is 2.3 which is

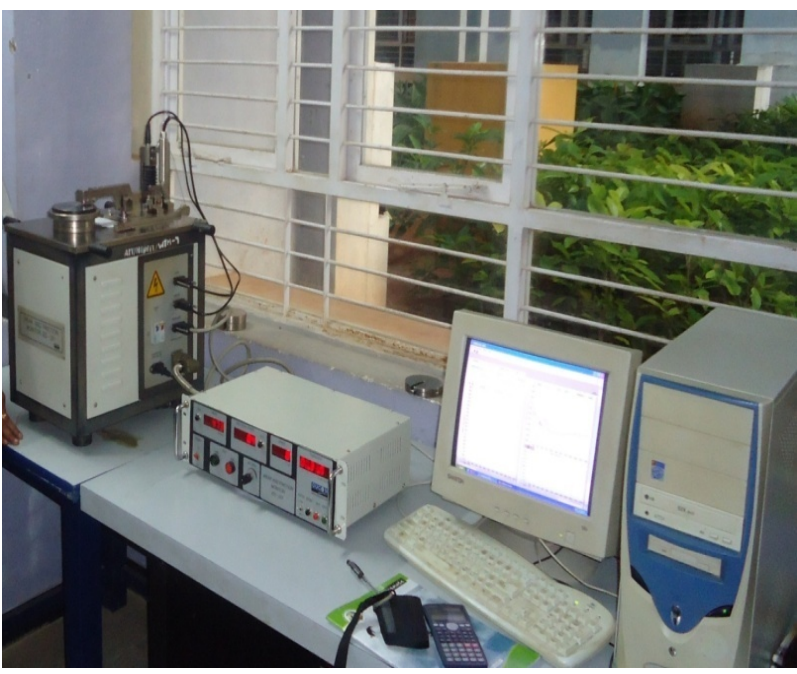

(a)

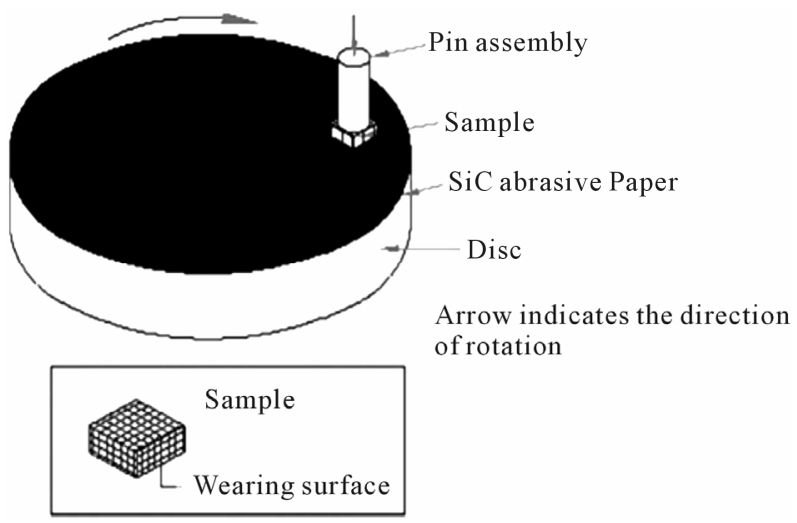

(b)

Figure 1. (a) Pin-on-disc wear test apparatus; (b) Rotating disc with SiC paper and composite sample.

Table 3. Physico-mechanical properties of $\mathrm{G}-\mathrm{E}$ and $\mathrm{Al}_{2} \mathrm{O}_{3}$ filled G-E composites.

\begin{tabular}{ccccc}
\hline Sample code & $\mathrm{G}-\mathrm{E}$ & $\begin{array}{c}5 \% \\
\mathrm{Al}_{2} \mathrm{O}_{3}-\mathrm{G}-\mathrm{E}\end{array}$ & $\begin{array}{c}7.5 \% \\
\mathrm{Al}_{2} \mathrm{O}_{3}-\mathrm{G}-\mathrm{E}\end{array}$ & $\begin{array}{c}10 \% \\
\mathrm{Al}_{2} \mathrm{O}_{3}-\mathrm{G}-\mathrm{E}\end{array}$ \\
\hline $\begin{array}{c}\text { Density, } \\
\left(\mathrm{g} / \mathrm{cm}^{3}\right)\end{array}$ & 1.984 & 2.12 & 2.23 & 2.3 \\
$\begin{array}{c}\text { Hardness } \\
(\text { Shore- } D)\end{array}$ & 63 & 66 & 69 & 72 \\
$\begin{array}{c}\text { Tensile strength, } \\
\sigma(\mathrm{MPa})\end{array}$ & 254 & 324 & 343 & 352 \\
$\begin{array}{c}\text { Tensile modulus, } \\
E(\mathrm{GPa})\end{array}$ & 8.34 & 10.6 & 11.26 & 11.55 \\
$\begin{array}{c}\text { Elongation, } \\
e(\mathrm{~mm})\end{array}$ & 7.1 & 6.4 & 6.2 & 5.9 \\
\hline
\end{tabular}

higher when compared to other composites. This is because of the filler $\mathrm{Al}_{2} \mathrm{O}_{3}$ has a higher density. The densities of all micro particles filled G-E is higher than the density of unfilled G-E composites. 


\subsection{Effect of Filler Loading on Hardness}

The hardness of G-E composite increased with increase of micro particle filler loading. By using the Duro-hardness tester, the hardness of the composites is measured; the values recorded are given in Table 3 , it can be seen that the $\mathrm{Al}_{2} \mathrm{O}_{3}$ filler greatly increased the hardness of $\mathrm{G}-\mathrm{E}$, which can be attributed to the higher hardness and more uniform dispersion of $\mathrm{Al}_{2} \mathrm{O}_{3}$ filler. The higher hardness is exhibited by the $10 \mathrm{wt} \% \mathrm{Al}_{2} \mathrm{O}_{3}$ filled $\mathrm{G}-\mathrm{E}$ compared to other composites. The hardness of $10 \mathrm{wt} \% \mathrm{Al}_{2} \mathrm{O}_{3}$ filled $\mathrm{G}-\mathrm{E}$ composite is 72 , which is highest among all the composites tested. Particulate filled G-E composites with sufficient surface hardness are resistant to in-service scratches that can compromise fatigue strength and lead to premature failure. Therefore, under an indentation loading, micro particles would undergo elastic rather than plastic deformation, as compared to unfilled G-E composites. The improvement in hardness with the incorporation of filler can be explained as follows: under the action of a compressive force, the thermoset matrix phase and the solid fiber and filler phase will be pressed together, touch each other and offer resistance. Thus the interface can transfer load more effectively although the interfacial bond may be poor. This results in enhancement of hardness of $\mathrm{Al}_{2} \mathrm{O}_{3}$ filled $\mathrm{G}-\mathrm{E}$ composites.

\subsection{Tensile Properties}

The typical load-deformation curves of unfilled and particulate filled G-E campsites are shown in Figure 2 and the measured mechanical test results are listed in Table 3. The average ultimate tensile strength values for $\mathrm{G}-\mathrm{E}$ composites with $0,5,7.5$ and $10 \mathrm{wt} \%$ of $\mathrm{Al}_{2} \mathrm{O}_{3}$ filler are 254, 324, 343 and $352 \mathrm{MPa}$, respectively. The tensile strength of the $\mathrm{Al}_{2} \mathrm{O}_{3}$ filled $\mathrm{G}-\mathrm{E}$ composites increased with increasing $\mathrm{Al}_{2} \mathrm{O}_{3}$ up to $7.5 \mathrm{wt} \%$, because of the uniform dispersion of $\mathrm{Al}_{2} \mathrm{O}_{3}$ filler in G-E. However, the in-

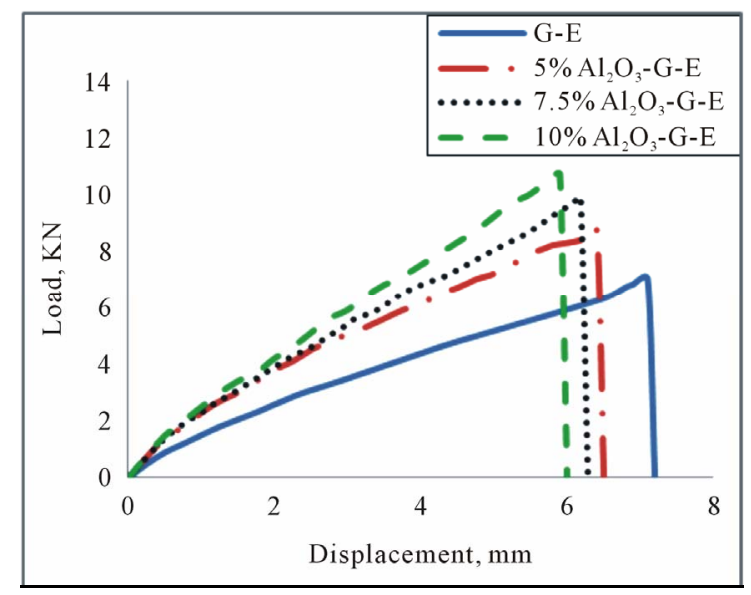

Figure 2. Typical load v/s displacement curves of G-E \& $\mathrm{Al}_{2} \mathrm{O}_{3}$ filled $\mathrm{G}-\mathrm{E}$ samples. crease in tensile strength is marginal beyond $7.5 \mathrm{wt} \%$ of $\mathrm{Al}_{2} \mathrm{O}_{3}$ filler loading. This could be attributed the uniform dispersion of $\mathrm{Al}_{2} \mathrm{O}_{3}$ filler in $\mathrm{G}-\mathrm{E}$. The surface modified $\mathrm{Al}_{2} \mathrm{O}_{3}$ can interact with the fiber surface and hydrogen bonding increases and leads to the better interaction with glass fiber and epoxy. Addition of ceramic fillers increases the effective mechanical interlocking, which in turn increases the frictional force between the fiber and matrix. It can be seen from Table 3 that the tensile modulus of $\mathrm{Al}_{2} \mathrm{O}_{3}$ filled G-E composites increases as the wt. fraction of the filler increases. Again there is a reduction in the elongation at break of the composites with an increase in the weight fraction of the filler. This is due to the fact that the $\mathrm{Al}_{2} \mathrm{O}_{3}$ filler is hard and also highly brittle. As the wt. fraction of $\mathrm{Al}_{2} \mathrm{O}_{3}$ filler increase, the tensile modulus of the G-E composites increases, but at the same time the system becomes more brittle. The increase in the tensile strength with wt. fraction of filler is attributed to the high modulus of ceramic filler which are dispersed uniformly in the fabric layers of G-E composites. Adding $\mathrm{Al}_{2} \mathrm{O}_{3}$ did not alter the tensile modulus appreciably except at $5 \mathrm{wt} \%$ filler loading. The average Young's modulus values for composites with $0,5,7.5$ and $10 \mathrm{wt} \%$ $\mathrm{Al}_{2} \mathrm{O}_{3}$ are 8.34, 10.6, 11.26 and $11.55 \mathrm{GPa}$, respectively. Young's modulus is mainly dependent on the matrix deformation of the composite and increases as the slope of the load-deformation curve at the initial stage and is practically not much influenced by the interfacial strength between fiber and matrix. Generally, the addition of ceramic fillers and glass fiber reduces the elongation at break because of the lower elongation at break values of ceramic fillers and glass fiber compared to that of epoxy matrix. Also the effects of filler loading on the mechanical properties of particulate filled G-E composites were studied and it can readily be seen from the data given in Table 3 and Figures 1(a) and (b).

At the filler loading $0-10 \mathrm{wt} \%$. Comparing the results, it can be seen that $\mathrm{Al}_{2} \mathrm{O}_{3}$ filled G-E samples show improved mechanical properties, confirming the effect of $\mathrm{Al}_{2} \mathrm{O}_{3}$ filler inclusion. The addition of $\mathrm{Al}_{2} \mathrm{O}_{3}$ particles causes a dispersion of these particles in the matrix which impede to the propagation of failure along the loading direction. Thus the failure would propagate easily in those directions where the dispersed concentration is less leading to increased tensile strength, tensile modulus, and lower elongation.

\subsection{Wear Volume}

The variation in abrasive wear volume of composites worn in 320 and 600 grit $\mathrm{SiC}$ paper at $10 \mathrm{~N}$ against abrading distance under multi-pass condition is shown in Figures 3(a) and (b) respectively. The wear data of the composites reveal that the wear volume tends to increase 


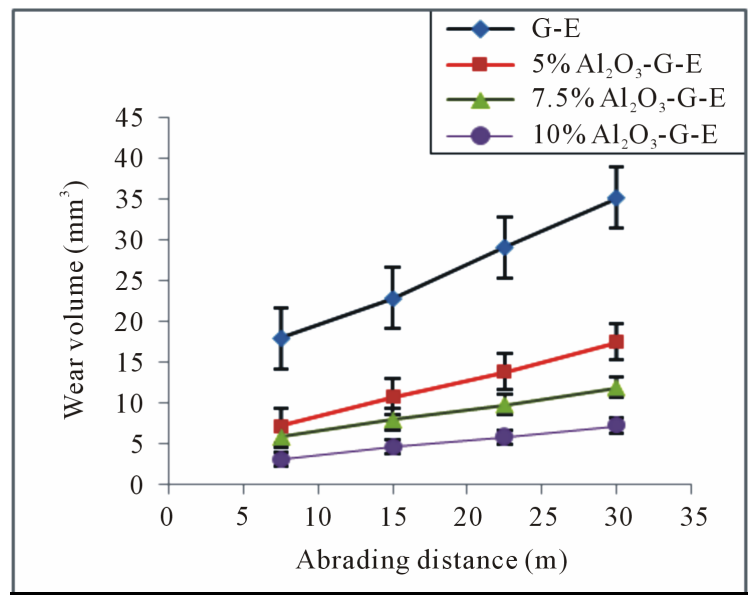

(a)

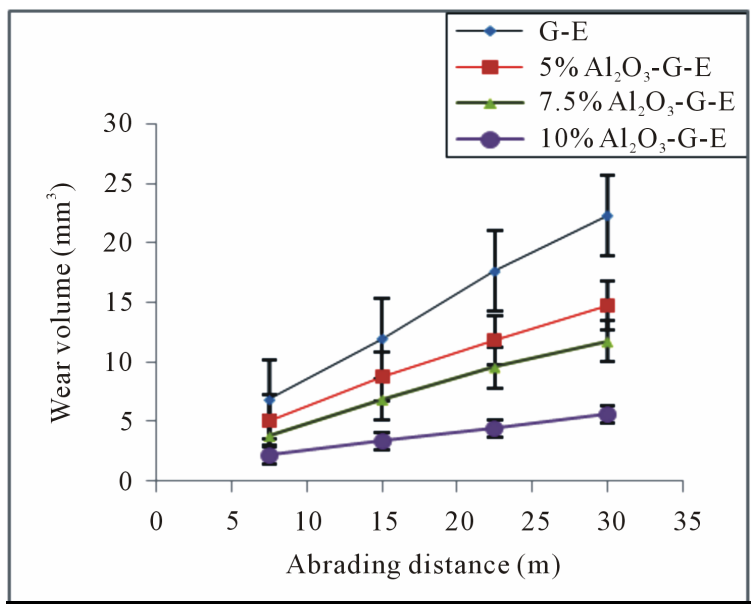

(b)

Figure 3. Variation of wear volume with abrading distance for unfilled and $\mathrm{Al}_{2} \mathrm{O}_{3}$ filled G-E composites: (a) 320 and (b) 600 grit $\mathrm{SiC}$ paper.

near linearly with increasing abrading distance and strongly depends on the grit size of the abrasive paper. From Figures 3(a) and (b), it is obvious that the wear volume of composites worn on two different $\mathrm{SiC}$ papers increased with increasing abrading distance. Wear volume of unfilled G-E is much higher than those of filled G-E composites and also the wear volume decreased with the increasing weight percentage of filler. In addition, the highest wear volume is obtained from specimens worn on 320 grit $\mathrm{SiC}$ paper Figure 3(a).

As shown in Figures 3(a) and (b), the wear volume of composites is 2.5 - 3.75 times greater than that of unfilled G-E composite. In the specimen worn at a load of $10 \mathrm{~N}$ with 320 grit $\mathrm{SiC}$, wear debris did not adhere to the $\mathrm{SiC}$ paper. However, in the specimen worn under the same test conditions except the grit size of $\mathrm{SiC}$ (600 grit); some abrasive particles penetrated more into the matrix. The fine particles which were detached from the counter surface (SiC paper) fill the cavities and modified the specimen surface. Therefore, the wear volume with 600 grit $\mathrm{SiC}$ paper decreased when compared to 320 grit $\mathrm{SiC}$ paper. The wear volume loss is less in $\mathrm{Al}_{2} \mathrm{O}_{3}$ filled $\mathrm{G}-\mathrm{E}$ composites and it can be attributed to inherent better mechanical properties and spherical shape of $\mathrm{Al}_{2} \mathrm{O}_{3}$. Also, G-E composites with $\mathrm{Al}_{2} \mathrm{O}_{3}$ filler addition, improved the mechanical properties listed in the Table 3.

\subsection{Specific Wear Rate}

The variation in the specific wear rate of composites worn on 320 and 600 grit $\mathrm{SiC}$ papers at $10 \mathrm{~N}$ against abrading distance is shown in Figures 4(a) and (b) respectively. There is a distinct difference between the specific wear rate behaviour.

It is clear from Figures 4(a) and (b) that the specific wear rate for $\mathrm{G}-\mathrm{E}$ and $\mathrm{Al}_{2} \mathrm{O}_{3}$ filled $\mathrm{G}-\mathrm{E}$ composites are increasing with abrading distance and decreased with an increase in the grit size of the $\mathrm{SiC}$ paper. This figure also

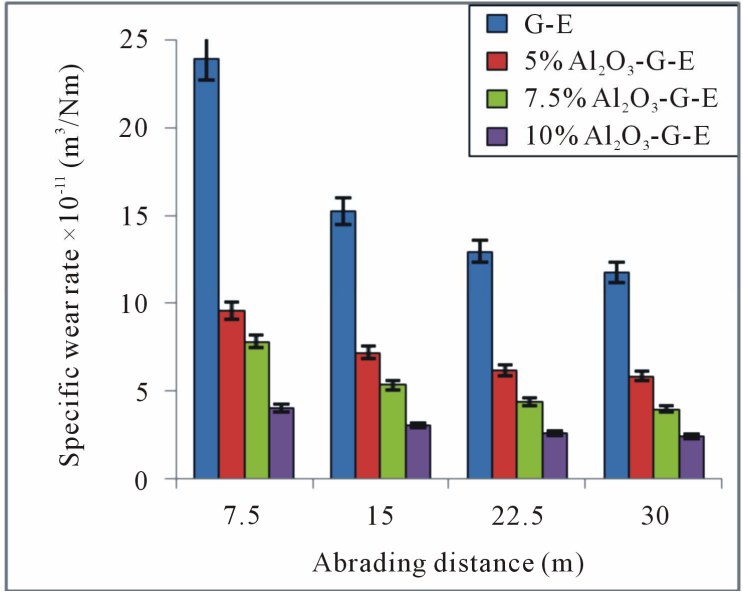

(a)

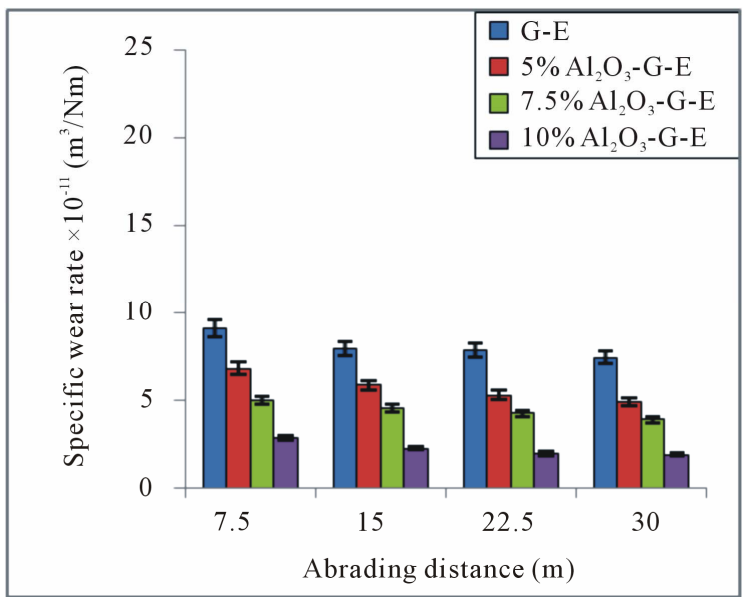

(b)

Figure 4. Variation of specific wear rate with abrading distance for unfilled and $\mathrm{Al}_{2} \mathrm{O}_{3}$ filled G-E composites: (a) 320 and (b) 600 grit $\mathrm{SiC}$ paper. 
shows that under higher abrading distance $(30 \mathrm{~m})$ the specific wear rate for $\mathrm{G}-\mathrm{E}$ and $\mathrm{Al}_{2} \mathrm{O}_{3}$ filled $\mathrm{G}-\mathrm{E}$ composite is following a decreasing trend. Above $15 \mathrm{~m}$ abrading distance (severe condition), the specific wear rate for G-E and $\mathrm{Al}_{2} \mathrm{O}_{3}$ filled G-E composite is following an increasing followed by stable trend. Generally there is the largest drop in specific wear rate for $\mathrm{G}-\mathrm{E}$ with the addition of $\mathrm{Al}_{2} \mathrm{O}_{3}$ filler. This behavior can be attributed to the presence of $\mathrm{Al}_{2} \mathrm{O}_{3}$, which is embedded within the matrix material, covers the packets of plain weave woven glass fabric and impart additional strength to the composite. Generally reinforcements in the form of fibers are sought to increase strength and specific modulus. This is so in conventional static and dynamic tests. In the case of wear, the interaction at the interface between the test specimen and the abrasive paper is a key factor. Lancaster [30] has shown the product of $\sigma$ and e (where $\sigma$ is the ultimate tensile strength and $e$ is the ultimate elongation) is a very important factor which controls the abrasive wear behaviour of composites.

Generally fiber/filler reinforcement increases the tensile strength $(\sigma)$ of neat polymer, they usually greatly decrease the ultimate elongation at break $(e)$ and hence the product $(\sigma \times e)$ may become smaller than that of neat polymer. Hence, reinforcement usually leads to deterioration in abrasive wear resistance. How these values get changed in the context of filler is a point that needs further investigation. The order of wear resistance behavior of composites is as follows: $10 \%>5 \%>0 \%$ by weight of $\mathrm{Al}_{2} \mathrm{O}_{3}$.

\subsection{Worn Surface Morphology (SEM Pictures Analysis)}

To correlate the wear data effectively, Scanning electron photomicrographs of worn surfaces of G-E and $10 \mathrm{wt} \%$ $\mathrm{Al}_{2} \mathrm{O}_{3}$ filled $\mathrm{G}-\mathrm{E}$ composite samples are shown in Figures 5(a) and (b) and Figures 6(a) and (b). Several mechanisms have been proposed to explain how material is removed from the surface during abrasion. Because of the complexity of abrasion, no one mechanism completely contributes to all the wear loss. In general, the abrasive wear process involves four different mechanisms namely microploughing, microcutting, microfatigue and microcracking. Using SEM photomicrographs it is possible to identify qualitatively the dominant wear mechanisms under abrasion.

Figure 5(a) shows scanning electron microscope (SEM) micrographs of glass fiber reinforced epoxy samples abraded against 320 grit $\mathrm{SiC}$ paper. Figure 5(a) shows some ploughing marks on the surface, matrix damage and exposure of glass fibers. These exposed fibers tend to fracture and their removal from the surface of the composite. The matrix is heavily damaged by ploughing and cutting action by the higher sized $\mathrm{SiC}$ particles. Overall surface topography indicated more fiber pulverization, more fiber breakage and less fiber-matrix debonding. The micrograph also indicates the crack propagation of the matrix, deterioration of the fiber-matrix adhesion due to repetitive mechanical stress and some fiber pullout from the matrix is also visible.

Figure 5(b) shows SEM pictures of unfilled G-E samples abraded against 600 grit abrasive papers. Further, few ploughing marks on the surface, matrix damage and very little exposure of glass fibers are seen from the SEM picture. The matrix is damaged more and more microcracks in the matrix are also visible from the micrograph. Further, smooth surface of the matrix and at some regions cracks and also voids are evident from the photomicrograph. This is attributed to the finer abrasive particles get crushed as the abrading distance increases and the $\mathrm{SiC}$ particles become ineffective. The SEM picture also indicates the deterioration of the fiber-matrix adhesion due to repetitive mechanical stress and debonding of fibers from the matrix.

Figures 6(a) and (b) show the SEM micrographs of

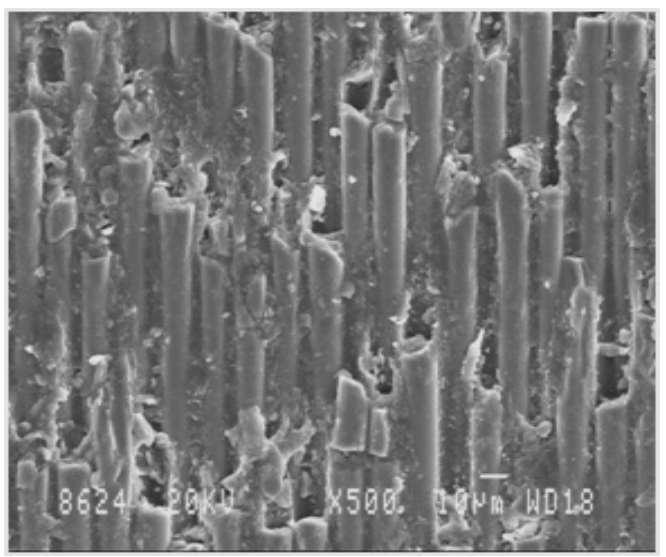

(a)

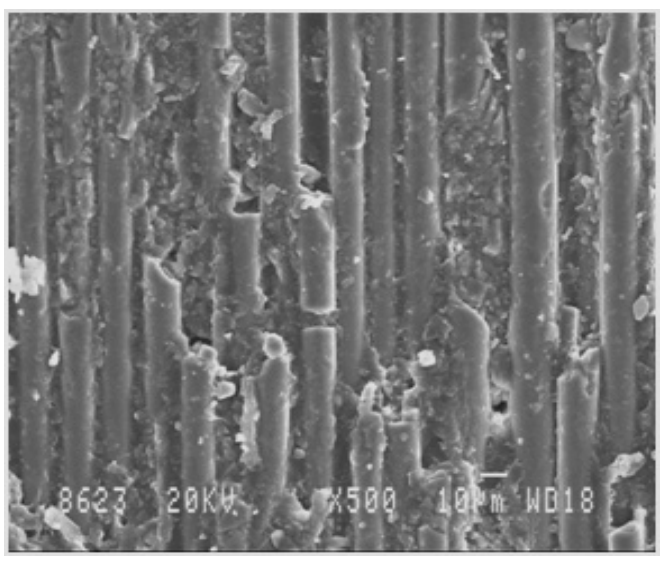

(b)

Figure 5. SEM micrographs of unfilled G-E composite using (a) 320 and (b) 600 grit $\mathrm{SiC}$ papers. 


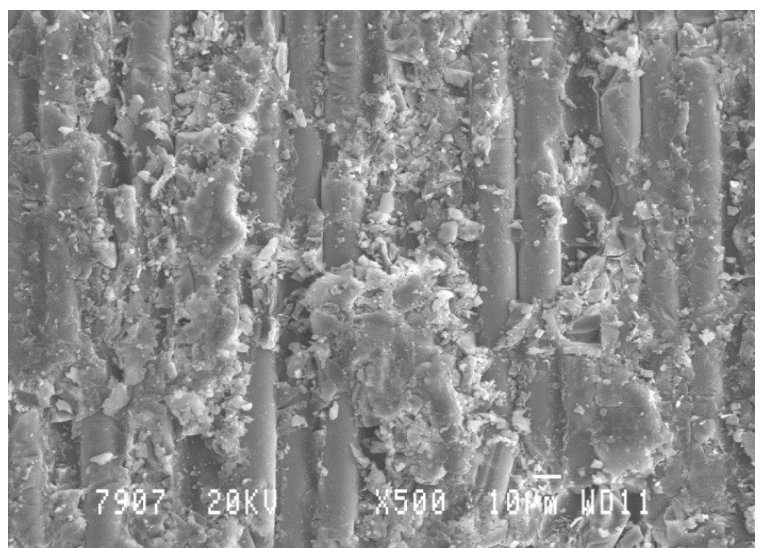

(a)

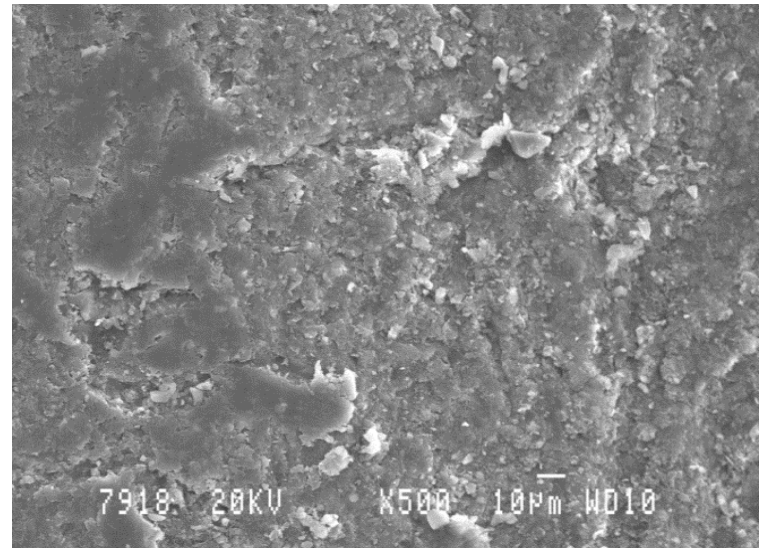

(b)

Figure 6. SEM micrographs of $10 \mathrm{wt} \% \mathrm{Al}_{2} \mathrm{O}_{3}$ filled G-E composite using (a) 320 and (b) 600 grit $\mathrm{SiC}$ papers.

the $10 \mathrm{wt} \% \mathrm{Al}_{2} \mathrm{O}_{3}$ filled G-E composite. Figures 6(a) and (b) exhibit the worn surfaces sliding against $\mathrm{SiC}$ paper having a grit size of 320 and 600, respectively. From Figures 6(a) and (b), it can be seen that in the both cases of abrasive grit size of 320 and 600 , there exist less wear debris on the worn surfaces, leading to improved wear resistance. On the worn surface of composite abraded against 320 grit $\mathrm{SiC}$ paper, the abrasive grooves are narrow and wider Figure 6(a). However, the worn surface of the same sample slide against 600 grit $\mathrm{SiC}$ paper indicate shallow and no grooves due to the smaller size of the abrasive particles Figure 6(b). Comparing the photomicrographs of the composites tested, the extent of damage is less in the case of $10 \mathrm{wt} \% \mathrm{Al}_{2} \mathrm{O}_{3}$ filled G-E composite.

\section{Conclusions}

The mechanical and tribological performances of G-E and $\mathrm{Al}_{2} \mathrm{O}_{3}$ filled $\mathrm{G}-\mathrm{E}$ composite were investigated and the following conclusions were drawn.

- The aluminium oxide filler addition to G-E samples has exceptionally improved the abrasive wear performance and the mechanical properties like tensile strength, tensile modulus and hardness properties;

- Two-body wear experimental results showed that the grit size of the abrasive paper greatly affected the wear rate of the composites;

- The wear volume loss increased in glass-epoxy composites with increasing the abrading distance;

- For the specific range of grit size of $\mathrm{SiC}$ paper and abrading distance explored in this study, the grit size of $\mathrm{SiC}$ paper has shown more influence on the wear behavior of $\mathrm{G}-\mathrm{E}$ and $\mathrm{Al}_{2} \mathrm{O}_{3}$ filled G-E composite than the abrading distance;

- In single-pass condition, cutting and multi-pass condition, microcracking and ploughing are the dominant wear mechanisms.

\section{REFERENCES}

[1] “ASM Handbook," ASM International, Materials Park, Vol. 18, 1992.

[2] K. Friedrich, Z. Lu and A. M. Hager, "Recent Advances in Polymer Composites Tribology," Wear, Vol. 190, No. 2, 1996, pp. 139-144. doi:10.1016/0043-1648(96)80012-3

[3] J. K. Lancaster, "The Effect of Carbon Fiber Reinforcement on Friction and Wear of Polymers," Journal of Physics D: Applied Physics, Vol. 1, No. 5, 1968, pp. 549-555.

[4] Z. Lu, K. Friedrich, W. Pannhorst and J. Heinz, "Wear and Friction of Unidirectional Carbon Fiber-Glass Matrix Composite against Various Counterparts," Wear, Vol. 162164, 1993, pp. 1103-1110. doi:10.1016/0043-1648(93)90129-A

[5] B. Viswnath, A. P. Verma and C. V. S. Kameswara Rao, "Effect of Reinforcement on Friction and Wear of Fabric Reinforced Polymer Composites," Wear, Vol. 167, No. 2, 1998, pp. 93-99. doi:10.1016/0043-1648(93)90313-B

[6] K. H. Zum Gahr, "Wear by Hard Particles," Tribology International, Vol. 31, No. 10, 1998, pp. 587-596. doi:10.1016/S0301-679X(98)00079-6

[7] I. M. Hutchings, "Mechanism of Wear in Powder Technology: A Review," Powder Technology, Vol. 76, No. 1, 1993, pp. 3-13. doi:10.1016/0032-5910(93)80035-9

[8] M. J. Neale and M. Gee, "Guide to Wear Problems and Testing for Industry," William Andrew Publishing, New York, 2001.

[9] "Standard Terminology Relating to Wear and Erosion," Annual Book of Standards, ASTM, Vol. 3, 1987, pp. 243250.

[10] K. N. Shivakumar, G. Swaminathan and M. Sharpe, "Carbon/Vinyl Ester Composites for Enhanced Performance in Marine Applications," Journal of Reinforced Plastics and Composites, Vol. 25, No. 10, 2006, pp. 1101-1116. doi:10.1177/0731684406065194

[11] B. Suresha, G. Chandramohan, P. Sampathkumaran, S. Seetharamu and S. Vynatheya, "Friction and Wear Characteristics of Carbon-Epoxy and Glass-Epoxy Woven Roving Fiber Composites," Journal of Reinforced Plastics and Composites, Vol. 25, No. 7, 2006, pp. 771-782. doi: $10.1177 / 0731684406063540$ 
[12] C. Soutis, "Carbon Fiber Reinforced Plastics in Aircraft Construction," Materials Science and Engineering: A, Vol. 412, No. 1-2, 2005, pp. 171-176. doi:10.1016/j.msea.2005.08.064

[13] J. Bijwe, R. Rattan and M. Fahim, "Erosive Wear of Carbon Fabric Reinforced Polyetherimide Composites: Role of Amount of Fabric and Processing Technique," Polymer Composites, Vol. 29, No. 3, 2008, pp. 337-344. doi:10.1002/pc. 20544

[14] R. Rattan and J. Bijwe, "Carbon Fabric Reinforced Polyetherimide Composites: Influence of Weave of Fabric and Processing Parameters on Performance Properties and Erosive Wear," Materials Science and Engineering: A, Vol. 420, No. 1-2, 2006, pp. 342-350. doi:10.1016/i.msea.2006.01.090

[15] J. L. Abot, A. Yasmin, A. J. Jacobsen and I. M. Daniel, "In-Plane Mechanical, Thermal and Viscoelastic Properties of a Satin Fabric Carbon/Epoxy Composite," Composites Science and Technology, Vol. 64, No. 2, 2004, pp. 263-268. doi:10.1016/S0266-3538(03)00279-3

[16] R. Park and J. Jang, "The Effects of Hybridization on the Mechanical Performance of Aramid/Polyethylene Intraply Fabric Composites," Composites Science and Technology, Vol. 58, No. 10, 1998, pp. 1621-1628. doi:10.1016/S0266-3538(97)00228-5

[17] J. Bijwe and R. Rattan, "Influence of Weave of Carbon Fabric in Polyetherimide Composites in Various Wear Situations," Wear, Vol. 263, No. 7-12, 2007, pp. 984-991. doi:10.1016/j.wear.2006.12.030

[18] W. I. J. Zaini, M. Y. A. Fuad, Z. Ismail, M. S. Mansor and J. Mustafah, "The Effect of Filler Content and Size on the Mechanical Properties of Polypropylene/Oil Palm Wood Flour Composite," Polymer International, Vol. 40, No. 1, 1996, pp. 51-55. doi:10.1002/(SICI)1097-0126(199605)40:1<51::AID-PI5 14>3.0.CO;2-I

[19] A. P. Harsha and U. S. Tewari, "Tribo Performance of Polyaryletherketone Composites," Polymer Testing, Vol. 21, No. 6, 2002, pp. 697-702. doi:10.1016/S0142-9418(01)00145-3

[20] B. Suresha, G. Chandramohan, Siddaramaiah, P. Sampathkumaran and S. Seetharamu, "Three-Body Abrasive Wear Behaviour of Carbon and Glass Fiber Reinforced Epoxy Composites," Materials Science and Engineering:
A, Vol. 443, No. 1-2, 2007, pp. 285-291. doi:10.1016/j.msea.2006.09.016

[21] D. C. Evans and J. K. Lancaster, "The Wear of Polymers," In: D. Scott, Ed., Treatise on Materials Science and Technology, Academic Press, New York, Vol. 13, 1979, pp. 85-139.

[22] P. H. Shipway and N. K. Ngao, "Microscale Abrasive Wear of Polymeric Materials," Wear, Vol. 255, No. 1-6, 2003, pp. 742-750. doi:10.1016/S0043-1648(03)00106-6

[23] M. Cirino, R. B. Pipes and K. Friedrich, "Evaluation of Polymer Composites for Sliding and Abrasive Wear Applacations," Composites, Vol. 19, No. 5, 1988, pp. 383392. doi:10.1016/0010-4361(88)90126-7

[24] M. Cirino, K. Friedrich and R. B. Pipes, "The Abrasive Wear Behaviour of Continuous Fiber Polymer Composites," Journal of Materials Science, Vol. 22, No. 7, 1987, pp. 235-247. doi:10.1007/BF01082134

[25] C. Lhymn, K. E. Tempelmeyer and P. K. Davis, "The Abrasive Wear of Short Fiber Composites," Composites, Vol. 16, No. 2, 1985, pp. 127-136. doi:10.1016/0010-4361(85)90619-6

[26] K. Friedrich, "Advances in Composite Technology," In: K. Friedrich and R. B. Pipes, Eds., Elsevier, The Netherlands, Vol. 8, 1993, pp. 209-276.

[27] K. Friedrich, "Wear Model for Multiphase Materials and Synergistic Effect in Polymeric Hybrid Composites," In: K. Friedrich and R. B. Pipes, Eds., Advances in Composite Technology, Composite Materials Series, Elsevier, The Netherlands, 1993.

[28] J. Bijwe, C. M. Logani and U. S. Tewari, "Influence of Fillers and Fiber Reinforcement on Abrasive Wear Resistance of Some Polymeric Composites," Proceeding of the International Conference on Wear of Materials, Denver, 8-14 April 1989, pp. 75-92.

[29] B. Suresha, G. Chandramohan, P. Sampathkumaran and S. Seethuramu, "Investigation of the Friction and Wear Behavior of Glass-Epoxy Composite with and without Graphite Filler," Journal of Reinforced Plastics and Composites, Vol. 26, No. 1, 2007, pp. 81-93. doi: $10.1177 / 0731684407069958$

[30] J. K. Lancaster, "Friction and Wear in Polymer Science," In: A. D. Jenkins, Ed., A Material Science Hand Book, North Holland, Amsterdam, 1972. 